\title{
Aaron Marcus
}

It's fair to say that Aaron Marcus has science in his blood. After more than 50 years of studying platelets, he shows no signs of slowing down.

The Veterans Affairs Medical Center on New York's East Side looms over a vast stretch of high-rises built to ease a housing crunch after World War II. Families began moving in during the summer of 1947, and by the time the complexes filled, they boasted the largest concentration of US veterans.

Aaron Marcus arrived here in 1958 to run the hospital's fledgling hematology-oncology division. Along with a faculty appointment at Cornell University, this center has served as his sole professional base.

Others might have traded on their success to move up, but Marcus insists there is nothing he would change. Among Marcus' many mottos: "As long as you're getting results, you can work in a trash can."

The drab, dimly lit hospital draws periodic predictions that it will be closed due to funding cutbacks, and the corridors of glazed brick and powder-blue paint give it the atmosphere of an old bus terminal.

"I still remember that creepy lab up on the thirteenth floor-it was creepy then, too," says Charles Serhan, who trained with Marcus as a fellow in the early 1980s. "[Marcus] was very clever about that, though, because all that glitters is not gold," says Serhan, director of The Center for Experimental Therapeutics at Brigham and Women's Hospital in Boston. "What seems to be like isolation gave him a sanctuary to create his Japanese garden of science."

As an 18-year-old pharmacist's mate in the US Navy in 1944, Marcus cared every day for 20 patients — casualties of the Pacific Island invasions of World War II — at an abandoned desert base near Palm Springs. He later pursued a career in clinical research, but remaining close to veterans has been an important factor in his lengthy tenure at the center.

"My family, especially my grandmother, always ridiculed me," says Marcus, who moves his jaw up and down, as if chewing a roll, in between sentences. "She thought, coming from Russia, that working for the government was the lowest form of work you could do. But I didn't mind it as long as each year was an improvement over the last."

Although his surroundings have remained inert, Marcus has managed to keep his work fluid. He is noted for classifying the molecular composition of platelets and for describing their role in the formation of blood clots (J. Clin. Invest. 41, 2198-2212; 1962). While studying the antithrombotic effect of aspirin in the 1970s, he discovered that platelets communicate with red and white blood cells to synthesize inflammatory agents and other metabolic products. Regulating these interactions, Marcus says, can block the formation of clots on atherosclerotic plaques in the blood vessels, a key antecedent of heart attack and stroke.

The US National Heart, Lung and Blood Institute recognized Marcus' results in 2004, awarding him a 10-year, \$2.8 million Method to Extend Research in Time grant to pursue a new regimen to augment traditional aspirin therapy as the next generation of antithrombotic agents. "You have to have what I call a 'macrocosmic view," Marcus says. "If you get a result with an experiment, whether in a test tube or in a patient, the first question I ask myself is, "how will this look three to five years from now?"”

Marcus' associates describe him as a purist-a meticulous investigator who never allows his zest for science to be diluted by entrepreneurial demands. "Aaron doesn't have a big lab_-almost all of his work, he does with his own hands," says Robert Schwartz, a deputy editor at the New England Journal of Medicine who met Marcus in 1954 when they were both training at Montefiore Medical Center. "He's not like those investigators with \$50 million grants and fellows whose last names he doesn't even know."
Drawing a modest paycheck and scant support quickly taught Marcus the value of grants. He received his first US National Institutes of Health (NIH) award in 1954 and, with the exception of a period in the 1960s, has enjoyed 50 years of virtually uninterrupted funding from the agency. His current grant has been renewed for 26 years, and according to Marcusthough officials say it's impossible to verify—he is the longest-running beneficiary of NIH support.

The rigors of fluctuating funds have taught Marcus about ingenuity. When a request to buy expensive gas chromatography equipment was rejected in the 1960s, Marcus procured the hulking machine one part at a time, debited his supply budget and assembled the unit from scratch. "We've done that over and over again," he says. "That's how I've survived."

Now widely accepted, Marcus' early description of transcellular metabolism was initially rejected for publication by a top-ranked journal. Not wishing to squander time on another peer review, Marcus settled for a lower journal and moved on.

"Marcus has always been able to find a way to sidestep the obstacles and stay focused," says Ralph Nachman, Cornell's chairman of medicine, who has worked with Marcus for more than 40 years. "He's a bit of a throwback to the old investigator, working on his own, and he sticks with it in spite of all the hullabaloo."

\section{"Any morning I get up and I have nothing more to say-that's when I won't go to work anymore."}

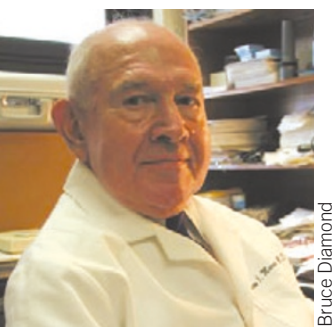

There were, to be sure, projects that didn't pan out. After years of work in the late 1970s, Marcus believed he was on the verge of isolating the receptor for serotonin. But an insurmountable snag in his methodology forced him to admit defeat. "I made the resolution then that I would only work in areas where one experiment would lead to another," he says.

Marcus also has devoted considerable energy to nurturing protégés, trying to act as the proper mentor he says he never had. He speaks fervently about recruiting and training young doctors to do translational research.

Marcus's current project is a recombinant form of the protein CD39, which he says controls blood fluidity (J. Clin. Invest. 99, 1351-1360; 1997). The protein, injected to supplement the body's supply, has been shown to inhibit clot formation in small animals, Marcus says, and could treat heart attack and stroke. He plans to test it in a baboon model of stroke before launching human trials.

The project consumes the bulk of his 16-hour workdays, but Marcus keeps taking on more work. He says he hopes to raise seed money to develop a center of excellence in vascular biology, at the Veterans Affairs hospital or at Cornell, that would assemble cardiologists, neurologists and vascular biologists to conduct research through interdisciplinary collaboration.

Marcus turns 80 in November, but becomes visibly irritated at any suggestion of tapering his workload. He says he is frequently asked when he plans to retire. "I always tell them the same thing," he says. "Any morning I get up and I have nothing more to say-that's when I won't go to work anymore."

Bruce Diamond, New York 